\title{
The Components of Mycoplasma salivarium and its Growth Medium that are Responsible for Film Formation
}

\author{
By HIROKO ICHIMARU AND M. NAKAMURA \\ Department of Microbiology, Kurume University, \\ School of Medicine, Kurume, 830, Japan
}

(Received 8 November 1978)

Studies on film production by mycoplasmas revealed that film was produced by completely disintegrated mycoplasma cells on Noble agar in the presence of horse serum. Film production was due to an enzymic reaction between mycoplasma lipase, possibly phospholipase A, and phospholipid in serum.

\section{INTRODUCTION}

Since the first description of film and spot production by some mycoplasma species by Edward $(1950 a, b)$, this phenomenon has been widely used as an aid for the classification and identification of mycoplasma species (Rottem \& Razin, 1964; Aluotto et al., 1970). Edward (1954) found that the film contained cholesterol and phospholipid and postulated that it might be produced by the action of lipases which digest phospholipid. Razin \& Rottem (1963) pointed out that granules and needles resembling the film appeared when a drop of pancreatic lipase solution was placed on plates of growth medium. Fabricant \& Freundt's (1967) report that film production was enhanced by addition of $10 \%$ egg yolk emulsion or lecithin to the growth medium suggested that the component of the solid medium required for film production might be phospholipid.

During experiments on mycoplasmacin (Nakamura et al., 1975; Nakamura, 1976), we discovered that film was produced by mycoplasmacin derived from mycoplasma cells that had been inactivated by ultrasonication and ultraviolet irradiation.

No detailed investigations of film production by mycoplasmas have been made. This paper describes a simple experimental system for studying factors affecting film and spot production, and some biochemical properties of mycoplasma cells and culture medium essential for the production of film.

\section{METHODS}

Strain. Mycoplasma salivarium-C Hup 127, maintained in our laboratory, was used throughout the experiments.

Medium. For growth of mycoplasma cells, enriched PPLO broth was used: this was composed of 70 vol. PPLO broth (Difco), $20 \mathrm{vol}$. horse serum and $10 \mathrm{vol.} 25 \%$ (w/v) freshly prepared yeast extract, supplemented with $0.0125 \%(\mathrm{w} / \mathrm{v})$ thallium acetate (Wako Co., Osaka, Japan) and $1000 \mathrm{U}$ penicillin G ml-1 (Meiji Co., Tokyo, Japan). Enriched PPLO agar contained 70 vol. PPLO agar (Difco) instead of PPLO broth, and it was distributed in 7 to $8 \mathrm{ml}$ amounts into Petri dishes $(65 \mathrm{~mm}$ diam.). When components were omitted from PPLO agar, they were replaced by an equal volume of phosphate-buffered saline. For $20 \%$ horse serum/ Noble agar, $20 \mathrm{ml}$ horse serum was added aseptically to $80 \mathrm{ml}$ of a sterilized solution of $1.5 \%(\mathrm{w} / \mathrm{v})$ Noble agar (Difco) in water.

Sera. Horse, bovine, calf, goat and rabbit sera were filtered through membrane filters (pore size $0.22 \mu \mathrm{m}$; Seitz or Millipore), heated at $56^{\circ} \mathrm{C}$ for $30 \mathrm{~min}$, and then stored at $-20^{\circ} \mathrm{C}$.

Medium for studying the effect of lipids on film production. Lipid (40 mg) was added to $40 \mathrm{ml} 1.5 \%$ Noble agar, and this mixture was autoclaved and then emulsified by ultrasonication $(19.5 \mathrm{kHz}, 3 \mathrm{~A}, 10 \mathrm{~min})$. For 0022-1287/79/0000-8444\$02.00@1979 SGM 
experiments with horse serum lipid, $3 \cdot 2 \mathrm{ml}$ lipid dissolved in chloroform were added to $100 \mathrm{ml}$ Noble agar. The homogenized agar was distributed in 7 to $8 \mathrm{ml}$ amounts into Petri dishes.

Observation of film production. For the intact mycoplasma, a single colony was observed under a microscope $(\times 40)$ at intervals in the course of film production. Inactivated cells or extracts were either directly inoculated on to solid medium, or $0.1 \mathrm{ml}$ samples were placed in wells (diam. $9 \mathrm{~mm}$ ) in the solid medium. Inoculated plates were incubated at $37^{\circ} \mathrm{C}$.

Preparation of cell extract. Mycoplasma cells (about $10^{9}$ colony-forming units $\mathrm{ml}^{-1}$ ) grown in liquid medium for $4 \mathrm{~d}$ at $37^{\circ} \mathrm{C}$ were collected by centrifugation at $9900 \mathrm{~g}$ for $60 \mathrm{~min}$. The cells were washed three times with distilled water, and then resuspended in distilled water $(1 / 50$ of the original culture volume) for ultrasonication $(19.5 \mathrm{kHz}, 3 \mathrm{~A}, 10 \mathrm{~min})$. The supernatant obtained by ultracentrifugation $(54000 \mathrm{~g}, 60 \mathrm{~min})$ of the ultrasonicated cell suspension still contained some viable mycoplasma cells. In order to inactivate these completely, samples were poured into a Petri dish (diam. $87 \mathrm{~mm}$ ) and irradiated with ultraviolet light (germicidal lamp, $15 \mathrm{~W}-\mathrm{G}$; Toshiba Electric Co., Tokyo, Japan) from a distance of $20 \mathrm{~cm}$ for 30 to $60 \mathrm{~min}$. These samples, which we refer to as 'cell-free extracts', were lyophilized and stored in a refrigerator.

Treatment of cell-free extracts. The $\mathrm{pH}$ stability of the film-producing ability of cell-free extracts was investigated in the $\mathrm{pH}$ range from 3 to 9 [pH 3 to 8 in McIlvaine's buffer ( $0 \cdot 1 \mathrm{M}$-citric acid, $\left.0 \cdot 2 \mathrm{M}_{-} \mathrm{Na}_{2} \mathrm{HPO}_{4}\right)$, pH 9 in Michaelis' veronal buffer $(0 \cdot 1 \mathrm{M}$-sodium barbiturate, $0 \cdot 1 \mathrm{M}-\mathrm{HCl})$ ] for $60 \mathrm{~min}$ at room temperature. The heat stability of samples suspended in water was tested by heating at $37,56,65,80$ and $100{ }^{\circ} \mathrm{C}$ for 30 min. The effect of dialysis against water for $18 \mathrm{~h}$ at $4{ }^{\circ} \mathrm{C}$ was tested. In all tests, lyophilized cell-free extract was suspended at $20 \mathrm{mg} \mathrm{ml}^{-1}$ and $0.1 \mathrm{ml}$ of the treated suspension was immediately added to a well in $20 \%$ horse serum/Noble agar. Loss of film-producing ability was observed microscopically during $14 \mathrm{~d}$ incubation at $37^{\circ} \mathrm{C}$.

Extraction of lipids from horse serum. The method employed was based on that of Bligh \& Dyer (1959). Horse serum $(125 \mathrm{ml})$ was shaken with $470 \mathrm{ml}$ chloroform/methanol $(1: 2, \mathrm{v} / \mathrm{v})$ and centrifuged at $890 \mathrm{~g}$ for $30 \mathrm{~min}$. The sediment was extracted with $580 \mathrm{ml}$ chloroform/methanol/water $(1: 2: 0 \cdot 8$, by vol.) and centrifuged. The combined supernatants were mixed with $2.5 \mathrm{vol}$. chloroform. An equal volume of distilled water was then added and mixed. The chloroform fraction obtained by centrifugation was mixed with an equal volume of benzene. Horse serum lipid was obtained from this mixture by rotary evaporation, and dissolved in $10 \mathrm{ml}$ chloroform.

Analysis of lipids. Phospholipids, total cholesterol and neutral lipids were measured by enzymic methods (Takahashi, 1974; Hess, 1964; Ansell, 1965).

Enzymes. Pancreatic lipase (unknown activity; Wako Co., Japan), wheat germ lipase (6 U mg-1; Sigma), phospholipase $\mathrm{A}_{2}$ (minimum $100 \mathrm{U} \mathrm{mg}^{-1}$, from snake venom; Boehringer-Mannheim), phospholipase $\mathrm{C}$ (1 to $2 \mathrm{U} \mathrm{mg}^{-1}$, from Clostridium perfringens; P-L Biochemicals) and phospholipase $\mathrm{D}\left(0.5 \mathrm{U} \mathrm{mg}^{-1}\right.$, from cabbage; P-L Biochemicals) were used.

Protein assay. Protein was measured by the method of Lowry et al. (1951) using bovine serum albumin fraction V (Armour Pharmaceutical Co.) as a standard.

\section{RESULTS AND DISCUSSION}

\section{Establishment of a simple experimental system for} studying film production by mycoplasmas

Previous observations (Nakamura, 1976) indicated that film was produced by inactivated mycoplasma cells. To identify the film-producing agent of mycoplasmas, we examined the effects of sonication, ultracentrifugation and ultraviolet irradiation on film-producing ability. Completely disrupted mycoplasma cells still produced a film on enriched PPLO agar. Therefore, a cell-free extract was used for all further experiments. To determine what components of enriched PPLO agar were essential for producing film, horse serum and yeast extract were omitted from complete PPLO agar or were added to $1.5 \%$ Noble agar. Film was not produced on PPLO agar without horse serum but it was observed on $1.5 \%$ Noble agar containing $20 \%$ horse serum without yeast extract (Fig. 1).

\section{Properties of film-producing ability of cell-free extract of $M$. salivarium}

The film-producing ability of the cell-free extract was weakened by heating for $30 \mathrm{~min}$ at $65^{\circ} \mathrm{C}$ and completely destroyed at $80^{\circ} \mathrm{C}$, but was not affected by changes in $\mathrm{pH}$ between 3 and 9 or by dialysis for $18 \mathrm{~h}$ at $4{ }^{\circ} \mathrm{C}$ against water. Therefore it seemed that the filmproducing agent in the cell-free extract might be a protein. The film-producing abilities of 


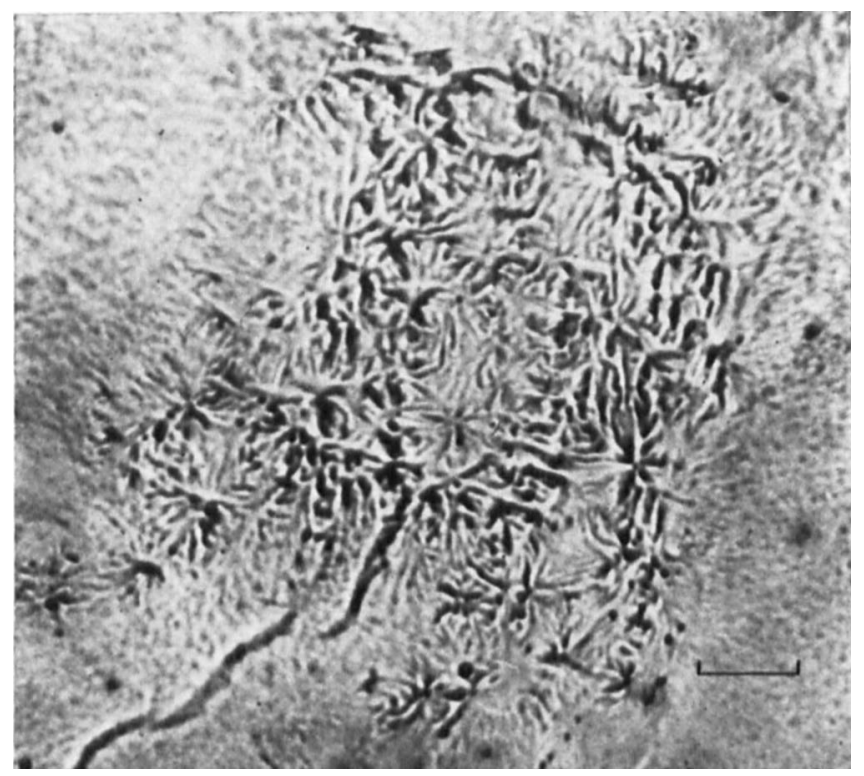

Fig. 1. Film production around a drop of cell-free extract of $M$. salivarium on the surface of $20 \%$ horse serum/Noble agar. Bar marker represents $0.25 \mathrm{~mm}$.

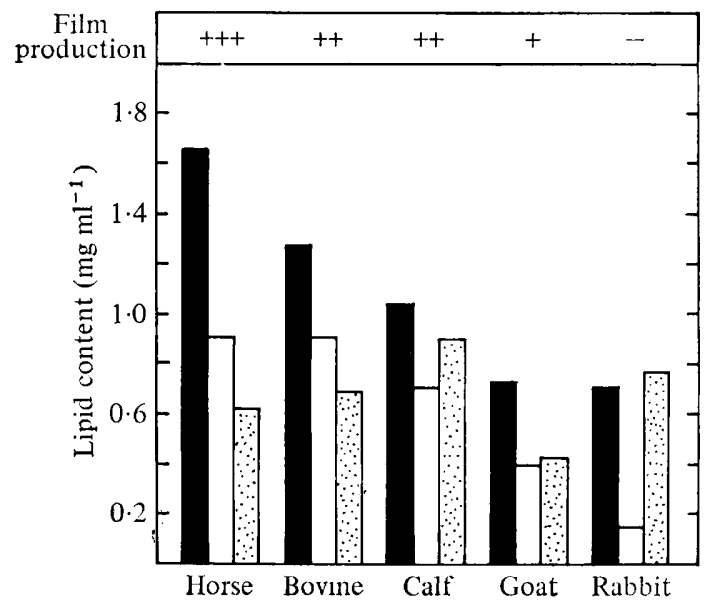

Fig. 2. Relationship between film production and the lipid contents of different types of serum: 口, phospholipids; $\square$, total cholesterol; 国, neutral lipids. Film production was tested using cell-free extract of $M$. salivarium: +++ , film production started after $2 \mathrm{~d}$ incubation and expanded over the whole surface of the agar; ++ , film production started after $3 \mathrm{~d}$ incubation and expanded over half the surface of the agar; + , film production started after $5 \mathrm{~d}$ incubation and was limited to about $1 \mathrm{~cm}$ diam.; - , no film production.

several types of lipase were tested, because film production by pancreatic lipase was rereported by Razin \& Rottem (1963). All commercial lipases tested, (pancreatic lipase, wheat germ lipase, phospholipases $A_{2}, C$ and D) produced film on $20 \%$ horse serum/ Noble agar, but to different extents; the strongest activity was found in phospholipase $A_{2}$, which was as active as the cell-free extract. The film-producing ability of phospholipase $A_{2}$ was not inactivated by heating at $65^{\circ} \mathrm{C}$ for $30 \mathrm{~min}$, but was slightly inactivated at 80 and $100{ }^{\circ} \mathrm{C}$, and was not affected by dialysis. It seemed that phospholipase $\mathrm{A}_{2}$ might be useful as a model of the film-producing agent of $M$. salivarium. The minimum concentration of horse serum in Noble agar that gave film production with phospholipase $A_{2}$ was $5 \%(\mathrm{v} / \mathrm{v})$ 
(5.2 $\mathrm{mg}$ protein $\mathrm{ml}^{-1}$ ). In $20 \%$ horse serum/Noble agar, $1 \cdot 5 \times 10^{-2}$ units of phospholipase $\mathrm{A}_{2}$ $(11.3 \mathrm{ng}$ protein) were able to produce the film.

\section{Film production by commercial lipids and lipid extracted from horse serum}

Fabricant \& Freundt (1967) reported that egg yolk emulsion, which mainly consists of lecithin, stimulated film production. Therefore film production by commercial lecithin, palmitic acid, tributyrin, cholesterol, cholesterol stearate and lipid extracted from horse serum was tested, using cell-free extract of $M$. salivarium or pancreatic lipase as the agent for producing film. The cell-free extract only produced film on Noble agar containing lecithin and pancreatic lipase only produced film on Noble agar containing either lecithin or lipid from horse serum. Thus an essential factor for film production was lecithin digested by lipase.

\section{Relationship between film production and different types of serum}

The relationship between the contents of phospholipids in several types of serum and film production was studied, using cell-free extract of $M$. salivarium or pancreatic lipase as the film-producing agent. There was a parallel relationship between the extent of film production and the contents of phospholipids and cholesterol, but not neutral lipids (Fig. 2). Pancreatic lipase also produced film in horse and bovine sera.

It is concluded that film production by mycoplasmas is mainly due to a reaction between a bacterial phospholipase A and lecithin in the growth medium. Although bacterial phospholipases $\mathrm{C}$ and $\mathrm{D}$ cannot release free fatty acids and lysolecithin from lecithin, they did have slight film-producing ability. It is possible that commercial phospholipases C and D contained a small amount of diesterase which was able to degrade lecithin to free fatty acids and lysolecithin.

\section{REFERENCES}

Aluotto, B. B., Wittler, R. G., Williams, C. O. \& FABER, J. E. (1970). Standardized bacteriologic techniques for the characterization of Mycoplasma species. International Journal of Systematic Bacteriology 20, 35--58.

ANSELL, G. B. (1965). The action of drugs on phospholipid metabolism. Advances in Lipid Research 3, 139-170.

Bligh, E. G. \& DYER, W. J. (1959). A rapid method of total lipid extraction and purification. Canadion Journal of Biochemistry and Physiology 37, 911917.

EDWARD, D. G. FF. (1950a). An investigation of pleuropneumonia-like organisms isolated from the bovine genital tract. Journal of General Microbiology 4, 4-15.

EDWARD. D. G. FF. $(1950 \mathrm{~b})$. An investigation of the biological properties of organisms of the pleuropneumonia group. Journal of General Microbiology 4, 311-329.

EDWARD, D. G. FF. (1954). The pleuropneumonia group of organisms. A review together with some new observations. Journal of General Microbiology 10, 27-64.

Fabricant, J. \& Freundr, E. A. (1967). Importance of extension and standardization of laboratory tests for the identification and classification of mycoplasma. Annals of the New York Academy of Sciences 143, 50-58.

HESS, R. (1964). Evaluation of drugs active against experimental atherosclerosis. Advances in Lipid Research 2, 295-445.

Lowry, O. H., Rosebrough, N. J., FARr, A. L. \& RANDALL, R. J. (1951). Protein measurement with the Folin phenol reagent. Journal of Biological Chemistry 193, 265-275.

NAKAMURA, M. (1976). Mycoplasma growth inhibitory substance (mycoplasmacin) derived from mycoplasmas. Proceedings of the Society for General Microbiology 3, 173.

Nakamura, M., Itoh, T. \& Hirata, N. (1975). Mycoplasmacin: mycoplasma growth inhibitory substance produced by mycoplasmas. Kurume Medical Journal 22, 219-221.

Razin, S. \& RotTeM, S. (1963). Fatty acid requirements of Mycoplasma laidlawii. Journal of General Microbiology 33, 459-470.

RotTEM, S. \& RAZIN, S. (1964). Lipase activity of mycoplasma. Journal of General Microbiology 37, 123-134.

TAKAHASHI, J. (1974). The determination of serum triglyceride by the enzymatic hydrolysis. Journal of Clinical Chemistry 2, 425-432. 